\title{
РІВНI МОНОЦИТАРНОГО ХЕМОАТРАКТАНТНОГО ПРОТЕЇНУ-1 У ХВОРИХ НА ЦУКРОВИЙ ДІАБЕТ 2 ТИПУ У ПОЄДНАННІ 3 ІШЕМІЧНОЮ ХВОРОБОЮ СЕРЦЯ
}

\author{
Серік С. А., Мавричева Н. Р., Ченчик Т. О. \\ ДУ «Національний інститут терапї̈ ім. Л. Т. Малої НАМН України», \\ л. Харків, Україна \\ mavrycheva@ukr.net
}

Цукровий діабет (ЦД) е потужним фактором ризику серцево-судинних захворювань та їх несприятливого перебігу. Паціенти з ЦД без серцево-судинних захворювань мають значно збільшений абсолютний ризик виникнення фатальної і нефатальної ішемічної хвороби серця (IXC) [1]. У хворих, які вже мають IXC, ЦД асоціюється з підвищенням ризику серцево-судинної смерті на $39 \%$, смерті від усіх причин - на 38 \%, інфаркту міокарда (IM) на $26 \%$ незалежно від демографічних даних, анамнезу, фракції викиду лівого шлуночка або застосування препаратів вторинної профілактики [2]. У паціентів з ЦД на 50 \% збільшуеться смертність у довгостроковому періоді після гострого IM, незалежно від типу IM та своєчасного лікування [3]. ЦД е потужним предиктором довгострокових несприятливих наслідків після перкутанного коронарного втручання
(ПКВ) з приводу стабільної IXC і гострого коронарного синдрому [4].

Механізми підвищеного ризику, прискореного розвитку та агресивного перебігу атеросклеротичних серцево-судинних захворювань при ЦД 2 типу остаточно не з'ясовані [5]. Поряд з гіперглікемією, дисліпідемією у якості одного з факторів, що обумовлюють тісний взаємозв'язок атеросклерозу і ЦД, розглядається хронічне системне запалення [5, 6]. Атеросклероз загальновизнано вважаеться системним запальним захворюванням зі збільшенням запальних біомаркерів у пацієнтів з прогресуючим атеросклерозом та запальним інфільтратом в атеросклеротичних бляшках [7]. Хронічний запальний стан, який називають метаболічним запаленням, е важливим компонентом патогенезу ЦД 2 типу [8]. Численні обсерваційні дослідження встановили підвищення рівнів запальних ме-

* Роботу виконано в рамках НДР відділу ішемічної хвороби серця і метаболічних порушень ДУ «Національний інститут терапії ім. Л. Т. Малої НАМН України» «Вивчити епігенетичні чинники метаболічного запалення при поєднанні ішемічної хворобі серця з цукровим діабетом 2 типу» (№ держреєстрації: 0120U000068).

Установою, що фінансуе дослідження, е НАМН України.

Автори гарантують колективну відповідальність за все, що опубліковано в статті.

Автори гарантують відсутність конфлікту інтересів та власної фінансової зацікавленості.

Рукопис надійшов до редакції 15.09.2021. 
діаторів, таких як C-реактивний протеїн, інтерлейкін-6 та інших, як головну ознаку асоціації між діабетом і атеросклерозом [9].

Моноцитарний хемоатрактантний протеїн-1 (МХП-1) - потужний запальний хемокін, що регулює активацію та хемотаксичну міграцію клітин-мішеней і сприяе запальним змінам на клітинному, плазменному та тканинному рівнях [10]. Відповідно до експериментальних даних МХП-1 відводиться важлива роль як на ранніх, так і на пізніх стадіях утворення атеросклеротичних уражень судин, формуванні уразливих бляшок [10]. Показано, що серед інших цитокінів МХП-1 має унікальний вплив на фрункцію адипоцитів, рекрутування макрофрагів жирової тканини та зв'язок між метаболічним запаленням та інсулінорезистентністю [11]. Передбачається, що МХП-1 є одним з хемокінів, з підвищеними концентраціями яких асоціюеться прогресування ЦД 2 типу [12].
В клінічних дослідженнях продемонстровано зв'язок вищих рівнів МХП-1 з ризиком IM та смерті від IXC, з вищою довгостроковою серцево-судинною смертністю осіб без явних серцево-судинних захворювань $[13,14]$. У хворих на IXC 3 документованим ураженням коронарних артерій виявлено підвищені рівні МХП-1 та встановлено його прогностичне значення щодо розвитку повторних серцево-судинних подій $[15,16]$. Відповідно до результатів останніх метааналізів рівні МХП-1 підвищуються у хворих на ЦД, а у пацієнтів 3 переддіабетом змін концентрацій цього хемокіну не виявлено [12, 17].

Метою нашого дослідження стало вивчення рівнів МХП-1 у хворих на ішемічну хворобу серця та при їі поєднанні з ЦД 2 типу у залежності від перенесеного в минулому інфаркта міокарду та перкутанного коронарного втручання.

\section{МАТЕРІАЛИ ТА МЕТОДИ}

У дослідження включено 31 хворого на стабільну IXC у поєднанні з ЦД 2 типу, та 26 хворих на IXC без ЦД 2 типу. Групу контролю склали 15 практично здорових осіб без IXC та ЦД. Дослідження проведено з дотриманням основних біоетичних положень Конвенції Ради Свропи про права людини та біомедицину (від 04.04.1997р.), Гельсінської декларації Всесвітньої медичної асоціації про етичні принципи проведення наукових медичних досліджень за участю людини (1964-2008 рр.), а також наказу МОЗ України № 690 від 23.09.2009 р. Всі пацієнти підписали інформовану згоду на участь у дослідженні.

Критеріями виключення були: гострий IM чи нестабільна стенокардія < 30 днів до включення у дослідження, зниження фрракції викиду лівого шлуночка < 40 \%; гемодинамічно значущі вади серця; ревматизм та інші системні захворювання сполучної тканини; гострі та декомпенсовані хронічні захворювання внутрішніх органів; тяжка ниркова недостатність (швидкість клубочкової фрільтрації (ШКФ) - менше 30 мл/хв./1,73 м²); печінкова недостатність; обструктивні захворювання легень; онко- логічні захворювання та інші захворювання з поганим прогнозом; ЦД 1 типу або інсулінозалежний; рівень тригліцеридів (ТГ) крові $\geq 4,5$ ммоль/л; рівень глікозильованого гемоглобіну $\geq 11 \%$.

Рівень МХП-1 у сироватці крові визначали імуноферментним методом 3 використанням набору реактивів «Вектор-Бест» (РФ). Рівні загального холестерину (ЗХC), ТГ і холестерину ліпопротеїнів високої щільності (ХС ЛПВЩ) в крові визначали ферментативним методом з використанням наборів реактивів Cormay (Польща). Вміст холестерину ліпопротеїнів низької щільності (ХС ЛПНЩ) розраховували за формулою Friedweald:

ХС ЛПНЩ = 3ХС $-($ ХС ЛПВЩ + ТГ/5).

Визначали рівень глікозильованого гемоглобіну (HbA1c) (\%) в крові фоотометричним іонообмінним методом 3 використанням тест-систем фірми Human GmbH (Німеччина). Для визначення вмісту інсуліну в сироватці крові використовували імуноферментний метод і набір реактивів «Insulin ELISA»(DRG Instruments GmbH, Німеччина). Показники глюкози крові натще визначали глюкозооксидазним методом 
3 використанням біохімічного аналізатора «Humalyzer 2000» (Німеччина). Індекс маси тіла (IMT) розраховували за фрормулою Кетле:

$$
\mathrm{IMT}=\text { вага }(к г) / 3 \operatorname{picT}^{2}\left(\mathrm{M}^{2}\right) .
$$

Статистична обробка даних проводилась за допомогою електронних таблиць Microsoft Excel та програми Statistica 6.0 (StatSoftInc, США, free version). Нормальність розподілу даних визначалася за допомогою критерію Шапіро-Уілка. За умови нормального розподілення кількісні дані представляли у вигляді середнього арифрметичного значення та стандартного відхилення $(\mathrm{M} \pm \sigma)$. Якщо розподіл показників у групах відрізнявся від нормального, дані були представлені у вигляді медіани та міжквартильного розмаху (Me [Q25-Q75]). Для оцінки статистичної значущості розбіжностей між групами використовувались t-критерій Стьюдента (при нормальному розподілі) та критерій Манна-Уітні з корекцією безперервності, для визначення характеру сили зв'язку між параметрами ранговий коефіцієнт кореляції Спірмана. Метод $\mathrm{X}^{2}$ з поправкою Йейтса використовували для визначення статистичних відмінностей у категоріальних групах. Достовірними вважали розбіжності при р <0,05.

\section{РЕЗУЛЬТАТИ ТА ЇХ ОБГОВОРЕННЯ}

Групи хворих на IXC без ЦД та IXC з ЦД 2 типу не відрізнялись за віком, статтю, наявністю артеріальної гіпертензії, IM в анамнезі (табл. 1). Не було також відмінностей за часткою хворих з проведеним в минулому ПКВ, давність якого в обох групах була більша за 1 рік. У пацієнтів з IXC та ЦД 2 типу IMT був більший, ніж у паціентів з IXC без ЦД 2 типу. У контрольній групі у порівнянні з хворими на IXC без ЦД та IXC з ЦД 2 типу обстежувані не відрізнялись за статтю, курінням в сьогоденні або минулому, але були молодші, не страж- дали на артеріальну гіпертензію та мали менший IMT.

Між хворими на IXC з ЦД 2 типу, IXC без ЦД 2 типу та контролем не було відмінностей за рівнями 3ХС і ХС ЛПНЩ (табл. 2). У хворих на IXC з ЦД 2 типу у порівнянні з пацієнтами з IXC без ЦД та контролем рівні ТГ були підвищені, відносно контрольної групи виявився зниженим ХC ЛПВЩ. У паціентів з IXC без ЦД рівень ТГ був більше, ніж у контрольній групі, a ХС ЛПВЩ від контролю не відрізнявся. Рівні глюкози крові натще, $\mathrm{HbA1c}$ та індекс

Клінічна характеристика обстежених

\begin{tabular}{|c|c|c|c|c|}
\hline Показник & $\begin{array}{c}\text { Контроль } \\
\mathbf{n}=15 \\
(1) \\
\end{array}$ & $\begin{array}{c}\text { IXC } \\
\mathrm{n}=26 \\
(2)\end{array}$ & $\begin{array}{c}\text { IXC з ЦД } 2 \text { типу } \\
\text { n = 31 } \\
\text { (3) }\end{array}$ & $\mathbf{p}^{*}$ \\
\hline Вік, роки $(\mathrm{M} \pm \sigma)$ & $36,27 \pm 9,94$ & $58,31 \pm 8,84$ & $60,67 \pm 8,00$ & $\begin{array}{l}\mathrm{p}_{1-2}<0,001 \\
\mathrm{p}_{1-3}<0,001\end{array}$ \\
\hline Стать (чоловіки, n (\%)) & $9(60,00 \%)$ & $21(80,76 \%)$ & $25(80,64 \%)$ & \\
\hline IM в анамнезі, n (\%) & - & $20(76,92 \%)$ & $20(64,51 \%)$ & \\
\hline ПКВ в анамнезі, n (\%) & - & $8(30,77 \%)$ & $7(22,58 \%)$ & \\
\hline $\begin{array}{c}\text { Артеріальна } \\
\text { гіпертензія, n (\%) }\end{array}$ & $0(0,00 \%)$ & $26(100,00 \%)$ & $31(100,00 \%)$ & $\begin{array}{l}\mathrm{p}_{1-2}<0,001 \\
\mathrm{p}_{1-3}<0,001\end{array}$ \\
\hline $\begin{array}{c}\text { Куріння } \\
\text { в сьогоденні або } \\
\text { минулому, n (\%) }\end{array}$ & $5(33,33 \%)$ & $12(46,15 \%)$ & $17(54,83 \%)$ & \\
\hline 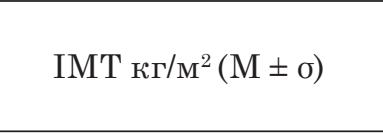 & $22,99 \pm 3,42$ & $29,8 \pm 4,5$ & $33,64 \pm 4,52$ & $\begin{array}{l}\mathrm{p}_{1-2}<0,001 \\
\mathrm{p}_{1-3}<0,001 \\
\mathrm{p}_{2-3}=0,004\end{array}$ \\
\hline
\end{tabular}

Примітка:

* вказано статистично значущі відмінності між показниками. 
Ліпідні і глюкометаболічні показники у хворих на IXC з ЦД 2 типу і без нього, Ме [Q25; Q75].

\begin{tabular}{|c|c|c|c|c|}
\hline Показник & $\begin{array}{c}\text { Контроль } \\
\mathrm{n}=15 \\
(1)\end{array}$ & $\begin{array}{c}\text { IXC } \\
n=26 \\
(2)\end{array}$ & $\begin{array}{c}\text { IXC з ЦД } 2 \text { типу } \\
\text { n=31 } \\
\text { (3) }\end{array}$ & $\mathbf{p}^{*}$ \\
\hline ЗХС, ммоль/л & $4,54[3,82 ; 4,81]$ & $4,16[3,34 ; 4,98]$ & $3,79[3,16 ; 5,55]$ & \\
\hline ХС ЛПВЩ, ммоль/л & $1,25[1,03 ; 1,37]$ & $1,06[0,85 ; 1,25]$ & $0,96[0,82 ; 1,12]$ & $\mathrm{p}_{1-3}=0,003$ \\
\hline ТГ, ммоль/л & $1,11[0,85 ; 1,34]$ & $1,51[1,22 ; 2,28]$ & $2,02[1,63 ; 2,88]$ & $\begin{array}{l}\mathrm{p}_{1-2}=0,003 \\
\mathrm{p}_{1-3}<0,001 \\
\mathrm{p}_{2-3}=0,026\end{array}$ \\
\hline ХС ЛПНЩ, ммоль/л & $2,71[2,52 ; 3,32]$ & $2,15[1,65 ; 2,82]$ & $1,78[1,23 ; 3,27]$ & \\
\hline $\begin{array}{c}\text { Глюкоза крові натще, } \\
\text { ммоль/л }\end{array}$ & $4,96[4,71 ; 5,57]$ & $5,87[5,20 ; 6,23]$ & $8,36[6,73 ; 11,79]$ & $\begin{array}{l}\mathrm{p}_{1-2}=0,001 \\
\mathrm{p}_{1-3}<0,001 \\
\mathrm{p}_{2-3}<0,001\end{array}$ \\
\hline HbA1c, \% & $4,90[4,50 ; 5,40]$ & $5,75[5,46 ; 6,13]$ & $6,79[5,6 ; 7,85]$ & $\begin{array}{l}\mathrm{p}_{1-2}=0,003 \\
\mathrm{p}_{1-3}<0,001 \\
\mathrm{p}_{2-3}=0,047\end{array}$ \\
\hline Інсулін, мкОД/мл & $\begin{array}{c}13,45 \\
{[11,35 ; 14,88]} \\
\end{array}$ & $\begin{array}{c}20,35 \\
{[15,04 ; 27,60]}\end{array}$ & $\begin{array}{c}22,75 \\
{[18,71 ; 30,34]}\end{array}$ & $\begin{array}{l}\mathrm{p}_{1-2}=0,004 \\
\mathrm{p}_{1-3}<0,001\end{array}$ \\
\hline HOMA-IR & $2,86[2,53 ; 3,68]$ & $5,32[3,98 ; 7,36]$ & $8,74[6,49 ; 14,93]$ & $\begin{array}{l}\mathrm{p}_{1-2}<0,001 \\
\mathrm{p}_{1-3}<0,001 \\
\mathrm{p}_{2-3}<0,001\end{array}$ \\
\hline
\end{tabular}

\section{Примітка:}

* вказані статистично значущі відмінності між показниками.

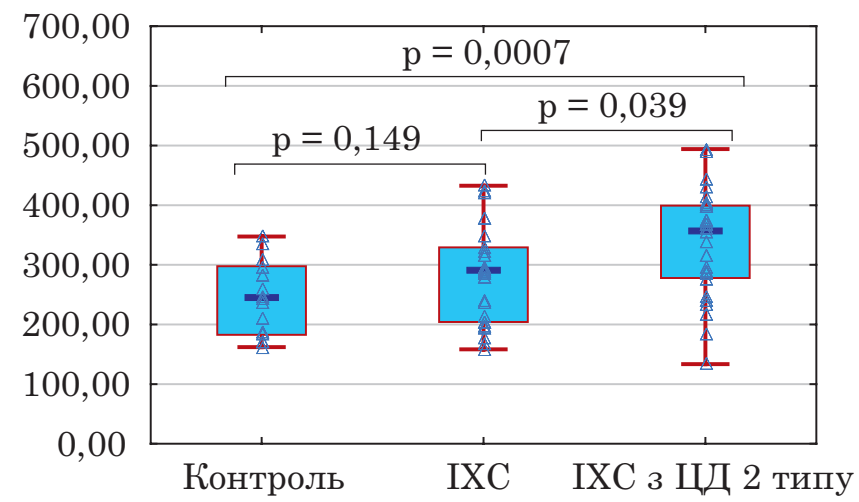

Рис. 1. Рівні МХП-1 у хворих на IXC з ЦД 2 типу і без нього.

HOMA-IR у хворих на IXC з ЦД 2 типу перевищували показники хворих на IXC без ЦД та контрольної групи. Рівні інсуліну у хворих на IXC з ЦД 2 типу та IXC без ЦД достовірно не відрізнялись і були більше, ніж групі контролю. Крім того, у хворих на IXC без ЦД відносно контролю були збільшені рівні глюкози крові, НbA1с та індекс HOMA-IR.

Рівень МХП-1 у хворих на IXC з ЦД 2 типу ((355,77 [278,01; 399,25]) пг/мл) виявився достовірно більше у порівнянні з контрольною групою $((244,64[182,67$;
297,77]) пг/мл) та хворими на IXC без ЦД $((289,28$ [204,17; 329,17]) пг/мл) (рис. 1). У хворих на IXC без ЦД значення МХП-1 були вищі, ніж в групі контролю, але розбіжності не відповідали критеріям значущості.

Отримані нами дані про зростання рівню МХП-1 у хворих на IXC з ЦД 2 типу узгоджуються результатами дослідження Ahmed S. F. із співавт., які виявили збільшення концентрацій МХП-1 у паціентів з IXC у поеднанні з ЦД 2 типу у порівнянні як з контролем, так і з хворими на ЦД 
2 типу та на IXC без ЦД [18]. Щодо змін МХП-1 у хворих на IXC без ЦД, то слід заначити, що поряд з вище наведеними результатами декількох досліджень, які продемонстрували про зростання рівнів хемокіну у пацієнтів з IXC, е дані і про його лише незначне збільшення у ціеї категорії хворих, як і в нашому дослідженні $[15,16,19]$.

За результатами кореляційного аналізу у хворих на IXC без ЦД виявлено значущий прямий зв'язок рівня МХП-1 з віком $(\mathrm{R}=0,41, \mathrm{p}=0,032)$ та IMT $(\mathrm{R}=0,39$, $\mathrm{p}=0,047)$. У хворих на IXC з ЦД 2 типу та контрольній групі кореляції МХП-1 з цими показниками були незначущими.

В дослідженнях in vitro продемонстровано, що гіперглікемія, ЛПНЩ здатні індукувати експресію МХП-1 [20, 21]. Нами очікуваних достовірних кореляцій рівню МХП-1 з глюкометаболічними та ліпідними показниками ні у хворих з ЦД 2 типу, ні у хворих без ЦД, ні в контрольній групі не виявлено. Вочевидь, на системну продукцію МХП-1 у хворих на IXC та ЦД 2 типу більший вплив справляють інші індуктори, основними з яких є прозапальні цитокіни, ростові фрактори, реактивні кисневі радикали, окислені ЛПНЩ [10].

У хворих на IXC з ЦД 2 типу з IM в анамнезі рівень МХП-1 був менше, ніж у хворих без IM, але розбіжності не досягли статистичної значущості (табл. 3). При цьому у пацієнтів і з IM в анамнезі, і без нього рівні МХП-1 достовірно перевищували показник контрольної групи ( $\mathrm{p}=0,003$, $\mathrm{p}=0,004$, відповідно). У хворих на IXC без ЦД з перенесеним IM рівень МХП-1 незначуще збільшувався відносно паціентів без IM. Проте і за ціеї умови рівні МХП-1 у хворих на IXC без ЦД у порівнянні з контролем відрізнялись недостовірно $(\mathrm{p}=0,109)$, а у хворих без постінфарктного кардіосклерозу рівень МХП-1 відносно контролю навіть дещо зменшувався $(\mathrm{p}=0,800)$.

У хворих на IXC з ЦД 2 типу, яким в минулому проведено ПКВ, рівень МХП-1 був достовірно вище, ніж у паціентів без ПКВ (див. табл. 3). При аналізі групи хворих на IXC без ЦД 2 типу у паціентів з ПКВ в анамнезі рівень МХП-1 навпаки виявився значуще нижчим відносно паціентів без ПКВ. У хворих на IXC з ЦД 2 типу без ПКВ та хворих на IXC без ПКВ рівні МХП-1 суттєво не відрізнялись. У пацієнтів з IXC та ЦД 2 типу після ПКВ рівень МХП1 був вище, ніж у паціентів з IXC без ЦД з ПКВ в анамнезі. При порівнянні з контрольною групою у паціентів з IXC без ЦД 2 типу без ПКВ встановлено достовірне збільшення рівню МХП-1 ( $\mathrm{p}=0,031)$, а у паціентів з IXC після ПКВ рівень МХП-1 від контролю не відрізнявся $(p=0,720)$. У хворих на IXC з ЦД 2 типу як без ПКВ, так і з ПКВ рівні МХП-1 значуще перевищували показник контрольної групи ( $\mathrm{p}=0,007, \mathrm{p}=0,0002$, відповідно).

Дуже пізні тромбози стента (більше ніж через 1 рік після ПКВ) є критичною проблемою після коронарного стентування, особливо серед пацієнтів з ЦД [22]. Важливим

Рівні МХП-1 у хворих на IXC з ЦД 2 типу та без нього в залежності від перенесеного в минулому IM та ПКВ

\begin{tabular}{c|c|c|c}
\hline $\begin{array}{c}\text { Групи } \\
\text { обстежених }\end{array}$ & $\begin{array}{c}\text { IXC } \\
\mathbf{( 1 )}\end{array}$ & $\begin{array}{c}\text { IXC з ЦД 2 типу } \\
\mathbf{( 2 )}\end{array}$ & $\mathbf{p}$ \\
\hline Без IM & $\begin{array}{c}241,84[177,16 ; 332,78] \\
\mathrm{n}=6\end{array}$ & $\begin{array}{c}367,06[240,82 ; 402,59] \\
\mathrm{n}=11\end{array}$ & $\mathrm{p}_{1-2}=0,170$ \\
\hline IM в анамнезі & $\begin{array}{c}293,48[215,35 ; 329,17] \\
\mathrm{n}=20\end{array}$ & $\begin{array}{c}327,76[282,19 ; 398,00] \\
\mathrm{n}=20\end{array}$ & $\mathrm{p}_{1-2}=0,157$ \\
\hline $\mathrm{p}=0,340$ & $\mathrm{p}=0,823$ & \\
\hline Без ПКВ & $\begin{array}{c}294,95[240,10 ; 348,66] \\
\mathrm{n}=18\end{array}$ & $\begin{array}{c}317,31[244,12 ; 371,15] \\
\mathrm{n}=24\end{array}$ & $\mathrm{p}_{1-2}=0,660$ \\
\hline ПКВ в анамнезі & $\begin{array}{c}199,715[179,68 ; 296,93] \\
\mathrm{n}=8\end{array}$ & $\begin{array}{c}399,25[355,77 ; 443,14] \\
\mathrm{n}=7\end{array}$ & $\mathrm{p}_{1-2}=0,004$ \\
\hline & $\mathrm{p}=0,030$ & $\mathrm{p}=0,038$ & \\
\hline
\end{tabular}


чинником, що сприяе пізнім серцево-судинним подіям, пов'язаним зі стентом, є неоатеросклероз, який виникає у стенті протягом набагато коротших часових проміжків, ніж природний атеросклероз - від 6 місяців до 5 років після встановлення, а не протягом усього життя. Передбачається, що хемокіни, зокрема МХП-1, відіграють ключову роль у розвитку неоатеросклерозу, як і при нативному атеросклерозі [23]. Не можна виключити, що встановлене нами ще більше зростання рівнів МХП-1 більше ніж через рік після ПКВ у хворих на IXC з ЦД 2 типу пов'язано з агресивним неоатеросклеротичним процесом (паралельно 3 нативним атеросклерозом) і може обумовлювати високий ризик дуже пізніх тромбозів стента або рестенозів в стенті, повторних реваскуляризацій і смертності саме при ЦД 2 типу.

Таким чином, результати нашого дослідженні свідчать про підвищення рівнів
МХП-1 у хворих на IXC лише при їі поєднанні з ЦД 2 типу, у найбільшому ступені після проведеного у віддаленому минулому ПКВ. При цьому значущих взаємозалежностей між МХП-1 і глюкометаболічними та ліпідними показниками не виявлено. 3 урахуванням визнаних проатерогенних властивостей МХП-1 можна передбачати потенційно специфічну, незалежну від метаболічних чинників роль МХП-1 у розвитку і прогресуванні атеросклеротичних та неоатеросклеротичних уражень при ЦД 2 типу.

Ймовірно, МХП-1 може слугувати маркером для діагностики, моніторування, прогнозування перебігу IXC у хворих на ЦД 2 типу. Але для підтвердження цих попередніх висновків необхідні дослідження у великих когортах пацієнтів з тривалим періодом спостереження.

\section{ВИСНОВКИ}

1. У хворих на ішемічну хворобу серця при їі поєднанні з ЦД 2 типу встановлено достовірне збільшення рівню МХП-1 не тільки у порівнянні з контролем, але й відносно хворих на ішемічну хворобу серця без цукрового діабету. У пацієнтів з ішемічною хворобою серця без цукрового діабету рівні хемокіну істотно не змінювались. Лише у хворих без цукрового діабету виявлено позитивні кореляції МХП-1 з віком та IMT.

2. Перенесений в минулому інфаркт міокарда не впливав на рівні МХП-1 у хворих на ішемічну хворобу серця ані з ЦД 2 типу, ані без цукрового діабету.
3. Значущі відмінності у рівнях МХП-1 встановлено у пацієнтів 3 проведеним у віддаленому (більше 1 року тому) періоді перкутанним коронарним втручанням і без нього. У хворих на ішемічну хворобу серця з ЦД 2 типу після перкутанного коронарного втручання рівень МХП-1 виявився достовірно більшим, ніж у пацієнтів без такого втручання. А у хворих без цукрового діабету, навпаки, проведення в минулому перкутанного коронарного втручання асоціювалось зі значним зменшенням МХП-1.

\section{ЛITЕРАТУРА (REFERENCES)}

1. Bancks MP, Ning H, Allen NB, et al. Diabetes Care 2019;42(3): 457-465. https://doi.org/10.2337/dc18-1773.

2. Mak K-H,Vidal-Petiot E, Young R, et al. Eur J Prev Cardiol 2021; zwab011. https://doi.org/10.1093/eurjpc/ zwab011.

3. Gholap NN, Achana FA, Davies MJ, et al. Diabetes Obes Metab 2017;19(3): 364-374. https://doi.org/10.1111/ dom.12827.

4. Chichareon P, Modolo R, Kogame N, et al. Atherosclerosis 2020;295: 45-53. https://doi.org/10.1016/j.atherosclerosis.2020.01.002.
5. Eckel RH, Bornfeldt KE, Goldberg IJ. Cell Metab 2021; 33(8): 1519-1545. https://doi.org/10.1016/j.cmet.2021. 07.001 .

6. Poznyak A, Grechko AV, Poggio P, et al. Int J Mol Sci 2020;21(5): 1835. https://doi.org/10.3390/ijms21051835.

7. Ministrini S, Carbone F, Montecucco F. Eur J Clin Invest 2021;51(5): e13467. https://doi.org/10.1111/eci.13467.

8. Galicia-Garcia U, Benito-Vicente A, Jebari S, et al. Int J Mol Sci 2020;21(17): 6275. https://doi.org/10.3390/ ijms21176275. 
9. La Sala L, Prattichizzo F, Ceriello A. Eur J Prev Cardiol 2019;26(2): 15-24. https://doi.org/10.1177/204748 7319878373 .

10. Bianconi V, Sahebkar A, Atkin SL, Pirro M. Curr Opin Hematol 2018;25(1): 44-51. https://doi.org/10.1097/MOH. 0000000000000389 .

11. Dommel S, Blüher M. Int J Mol Sci 2021;22(3): 1500. https://doi.org/10.3390/ijms22031500.

12. Pan X, Kaminga AC, Wen SW, Liu A. Front Immunol 2021;12: 622438. https://doi.org/10.3389/fimmu.2021. 622438 .

13. Schiopu A, Bengtsson E, Gonçalves I, et al. $J A m$ Heart Assoc 2016;5(9): e002851. https://doi.org/10.1161/ JAHA.115.002851.

14. Georgakis MK, de Lemos JA, Ayers C, et al. JAMA Cardiol 2021;6(5): 587-592. https://doi.org/10.1001/jamacardio.2020.5392.

15. Li J, Zhang Y, Guo X, et al. Pharmgenomics Pers Med 2021;14: 553-559. https://doi.org/10.2147/PGPM.S303362.

16. Blanco-Colio LM, Méndez-Barbero N, Pello Lázaro AM, et al. J Clin Med 2021;10(5): 1137. https://doi.org/10. 3390/jcm10051137.
17. Georgakis MK, Malik R, Björkbacka H, et al. Circ Res 2019;125(8): 773-782. https://doi.org/10.1161/ CIRCRESAHA.119.315380.

18. Ahmed SF, Shabayek MI, Abdel Ghany ME, et al. PLoS One 2018;13(12): e0208038. https://doi.org/10.1371/journal.pone.0208038.

19. Subirana I, Fitó M, Diaz O, et al. Sci Rep 2018;8(1): 3191. https://doi.org/10.1038/s41598-018-21482-y.

20. Macarie RD, Vadana M, Ciortan L, et al. J Cell Mol Med 2018;22(9): 4366-4376. https://doi.org/10.1111/ jcmm.13728.

21. Jia S, Yang S, Du P, et al. Front Genet 2019;10: 1098. https://doi.org/10.3389/fgene.2019.01098.

22. Zhao X, Lan J, Yu X, et al. Front Cardiovasc Med 2021;8: 653467. https://doi.org/10.3389/fcvm.2021.653467.

23. Ravindran D, Galougahi KK, Tan JTM, et al. Cardiovasc Res 2020: cvaa072. https://doi.org/10.1093/cvr/ cvaa072. 


\title{
РІВНI МОНОЦИТАРНОГО ХЕМОАТРАКТАНТНОГО ПРОТЕЇНУ-1 У ХВОРИХ НА ЦУКРОВИЙ ДІАБЕТ 2 ТИПУ У ПОЄДНАННІ З ІШЕМІЧНОЮ ХВОРОБОЮ СЕРЦЯ
}

\author{
Серік С. А., Мавричева Н. Р., Ченчик Т. О. \\ ДУ “Національний інститут терапії ім. Л.Т. Малої НАМН України», \\ м. Харків, Україна \\ mavrycheva@ukr.net
}

Механізми атеросклеротичних серцево-судинних захворювань при цукровому діабеті (ЦД) остаточно не визначені. Моноцитарний хемоатрактантний протеїн-1 (МХП-1) е прозапальним хемокіном, який відіграє ключову роль у патофізіології як атеросклерозу, так і діабету.

Мета дослідження: вивчити рівні МХП-1 у хворих на IXC з ЦД 2 типу у залежності від перенесеного в минулому інфаркту міокарда та перкутанного коронарного втручання (ПКВ).

Матеріали і методи. У 31 хворого на стабільну IXC з ЦД 2 типу, 26 паціентів з IXC без ЦД, 15 осіб контрольної групи визначали сироваткові рівні МХП-1 імуноферментним методом.

Результати. Рівні МХП-1 у хворих на IXC з ЦД 2 типу були вище, ніж в осіб контрольної групи ( $p=0,0007)$ та у пацієнтів з IXC без ЦД ( $p=0,039)$. У хворих на IXC без ЦД рівні МХП-1 збільшувались незначуще. Кореляцій рівню МХП-1 з глюкометаболічними та ліпідними показниками в жодній групі не виявлено. У хворих і з ЦД 2 типу, і без ЦД не встановлено істотних відмінностей у рівнях МХП-1 між паціентами з і без інфаркту міокарда. У хворих на IXC з ЦД 2 типу, які мали в анамнезі ПКВ давністю більшою за 1 рік, рівень МХП-1 був достовірно вище, ніж у паціентів без ПКВ $(\mathrm{p}=0,038)$. У хворих на IXC без ЦД 2 типу з проведеним в минулому ПКВ рівень МХП-1 виявився значуще меншим відносно пацієнтів без ПКВ ( $=0,030)$.

Висновки. У хворих на ішемічну хворобу серця з ЦД 2 типу рівень МХП-1 збільшувався у порівнянні з контролем та пацієнтами з ішемічною хворобою серця без цукрового діабету. Хворі на ішемічну хворобу серця з ЦД 2 типу з перкутанним коронарним втручанням в анамнезі мали найвищий рівень МХП-1.

К лючові слова : ішемічна хвороба серця, цукровий діабет 2 типу, моноцитарний хемоатрактантний протеїн-1.

\section{MONOCYTE CHEMOATTRACTANT PROTEIN-1 LEVELS IN PATIENTS WITH TYPE 2 DIABETES MELLITUS AND CORONARY ARTERY DISEASE}

\author{
S. A. Serik, N. R. Mavrycheva, T. O. Chenchyk \\ GI «L.T. Malaya Therapy National Institute of the NAMS of Ukraine», \\ Kharkiv, Ukraine \\ mavrycheva@ukr.net
}

Mechanisms of atherosclerotic cardiovascular diseases in patients with diabetes mellitus have not been fully clarified. Monocyte chemoattractant protein-1 (MCP-1) is a proinflammatory chemokine which plays a key role in the pathophysiology of both atherosclerosis and diabetes. The aim of the study was to investigate MCP-1 levels in patients with coronary artery disease (CAD) with type 2 diabetes mellitus (T2DM) depending on previous history of myocardial infarction and percutaneous coronary intervention (PCI).

Materials and Methods. Serum MCP-1 levels were measured in 31 patients with stable CAD with T2DM, 26 non-DM patients with CAD and 15 control group persons.

Results. MCP-1 level in patients with CAD with T2DM was higher than in the control group $(p=0,0007)$ and non-DM patients with CAD ( $p=0,039)$. The elevation of MCP-1 level in non-DM patients with CAD was insignificant. There were no correlations of MCP-1 levels with glucometabolic and lipid indices in any groups. MCP-1 levels did not differ significantly in CAD patients with and without a history of previous myocardial infarction both in non-DM patients and in patients with T2DM. CAD patients with T2DM with a history of PCI more than 1 year previously have higher MCP-1 levels than CAD patients with T2DM without a history of PCI $(p=0,038)$. In non-DM patients with CAD with the same history of PCI MCP-1 decreased compared to non-DM patients without previous PCI $(p=0,030)$.

Conclusions. In patients with CAD with T2DM MCP-1 level increased in comparison with the controls and CAD patients without T2DM. CAD patients with T2DM with a history of PCI have highest MCP-1 level.

Keywords: coronary artery disease, type 2 diabetes mellitus, monocyte chemoattractant protein- 1. 